\title{
A gyakorlóiskola szerepe a pedagógusjelöltek felkészítésében
}

\author{
Orgoványi-Gajdos Judit
}

az Eszterházy Károly Egyetem Pedagógiai Karának adjunktusa

orgovanyi.gajdos.judit@uni-eszerhazy.hu

Hazai és nemzetközi szakirodalmi adatokkal egyaránt igazolható, hogy a pedagóguspályát választó hallgatók számos területen elégedetlenek a tanárképzéssel (Lukács 2002; Kocsis, 2003; Jancsák 2011, 2012). Ezeket a visszajelzéseket a már pályán lévő kezdő tanárok problémáival foglalkozó kutatások is nagyban megerósítik (Hagger - McIntyre, 2006; OECD, 2009; Fehérvári 2016). Az Eszterházy Károly Egyetem Gyakorlóiskoláját érintő 2017-ben zajló kutatás célja az volt, hogy egy esettanulmányon keresztül megvizsgálja a problémakörrel kapcsolatos jelenlegi hazai helyzetet, és a Szakmai Fejlesztő Iskola koncepciójából kiindulva megoldási javaslatokat nyújtson a fejlesztés lehetséges irányaival kapcsolatban.

Kulcsszavak: tanárképzés, tanárjelöltek, gyakorlóiskola és egyetem kapcsolata

DOI: 10.37205/TEL-hun.2019.1-2.05

\section{Bevezető}

Korábbi hazai felmérések rámutattak arra, hogy a hallgatók nagymértékben elégedetlenek a tanárképzés egyes aspektusaival. A pedagógusjelöltek úgy érzik, az egyetemi kurzusok teoretikus anyagát nem tudják megfelelően hasznosítatni a tanítási gyakorlatban, viszont a képzés nem szentel kellő figyelmet azon kompetenciák fejlesztésére, amelyekre igazán szükségük lenne a tanulási-tanítási folyamat hatékony irányításához (Kocsis, 2003; Lukács, 2002; Jancsák, 2011, 2012). Különösen az óraszervezéssel-óravezetéssel kapcsolatos feladatokra való felkészítés területein észlelnek hiányosságokat. Az egyik ilyen terület az osztályirányítás (fegyelmezés, csoportirányítás, konfliktuskezelés) a másik az egyéni bánásmódot igénylő tanulók köre (SNI, tehetséges tanuló), a harmadik a szülőkkel való együttmüködés (N. Kollár, 2011; Jancsák, 2012). Ezek az adatok egybecsengenek a kezdő pedagógusok kihívásaival foglalkozó hazai és nemzetközi kutatásokkal is (Hagger McIntyre, 2006; OECD, 2009; Fehérvári, 2016).

Az okok között egyfelől egy nemzetközi szinten is tapasztalható jelenséget találunk, mégpedig, hogy az egyetemi képzések tantervi kínálatában a pedagógiai, 
pszichológiai, szakmódszertani modulok egymástól elszigetelten jelennek meg, a valós tanári gyakorlatba pedig már csak töredékük épül be (Feiman-Nemser, 2001; Hagger - McIntyre, 2006; Cooper, 2011). Másrészről, mivel a tanári professzió számos eleme alapvetően a gyakorlathoz kapcsolódik, ezért leginkább az osztálytermi gyakorlat során fejleszthető. Nem véletlen, hogy a tanárjelöltek és a kezdő pedagógusok a képzési rendszer leghatékonyabb elemének a gyakorlótanítást tartják (Lukács, 2002; Kocsis, 2003; N. Kollár, 2008, 2011; Jancsák, 2011, 2012). Ennek hatására a nemzetközi fejlesztési tendenciák alapján egy sokkal gyakorlatiasabb irány (practical turn) látszik körvonalazódni (Murray, 2019). Ez megnyilvánul egyfelől az iskolai gyakorlatok diverzitásában, a gyakorlati idő növekedésében, a képzőintézmények és az oktatók közötti új partnerségi modellek kialakításában, valamint a neveléstudományi kutatások szerepének megerősödésében a képzés minden szintjén (Zeichner, 2010; Kopp - Kálmán, 2015; Murray, 2019).

A Szakmai Fejlesztő Iskola (Professional Development School, PDS) modell azért lehet iránymutató e tekintetben, mert felhívja a figyelmet arra, hogy a tanárképzésben részt vevő intézmények, a gyermekek és a hallgatók tanulási szükségleteire épülő kutató-fejlesztő munkát középpontba állító, közös problémamegoldásra épülő együttműködése elengedhetetlen ahhoz, hogy a képzés céljai ténylegesen megvalósuljanak és a pedagógusjelölt hallgatók felkészítése hatékonnyá váljon. Ennek alapfeltétele, hogy a képzéshez kapcsolódó partnerintézmények, illetve a tanárképzésben érintett résztvevők között egyenrangú viszony alakuljon ki. A koncepció kihangsúlyozza azt is, hogy a szakmai tanulóközösség tagjai az egyetem és a gyakorlóhely oktatóin kívül más külső oktatók (például gyógypedagógus), valamint a szülők is, akik hasznos információkkal szolgálhatnak a tanárjelöltek számára (Darling-Hammond, 1994; Krist - White - Whitelaw, 2016).

\section{A kutatás jellemzői}

A tanulmány alapját képező kutatás a gyakorlóiskolák tanárképzésben betöltött szerepét illetve hatékonyságát vizsgálta az Eszterházy Károly Egyetem Gyakorlóiskola esettanulmányán keresztül. Arra kereste a választ, hogy a Szakmai Fejlesztő Iskolává (PDS) válás, milyen lehetőségeket rejt a gyakorlóintézmények hatékony működésére vonatkozóan, különös tekintettel a hallgatók tanári mesterségre történő professzionális felkészítésére. A kutatási mintát az Eszterházy Károly Egyetem Gyakorlóiskolai képzéséhez kapcsolódó, MA-képzésben részt vevő hallgatók $(\mathrm{N}=22)$, egyetemen tanító szakmódszertanos oktatók $(\mathrm{N}=16)$ és az egri gyakorlóis- 
kolában tanító pedagógusok $(\mathrm{N}=102)$ alkották. A kutatási kérdések az alábbi témák köré csoportosultak:

- A tanárjelöltek, egyetemi oktatók és pedagógusok szerint, milyen mértékben teljesülnek a gyakorlóiskola által kitűzött célok a tanítási gyakorlatok tekintetében?

- Milyen mértékben segítik a hallgatók szakmai fejlődését az iskolai gyakorlatok során végezendő különböző feladatok és tevékenységek?

- Milyen típusú tanórai vagy tanórán kívüli foglalkozásokon volt lehetőségük a hallgatóknak megfigyelőként vagy foglalkozásvezetőként részt venni?

- Milyen mértékben elégedettek a hallgatók saját szaktárgyi (tudományos), pedagógiai-pszichológiai és szakmódszertani (tantárgypedagógiai) felkészültségükkel?

- A hallgatók, a vezetőtanárok és az egyetemi oktatók szerint a képzés mely területei biztosítják leginkább a tanári professzióra való felkészülést?

- Melyek a jelöltek tanári kompetenciáinak legmarkánsabb és leggyengébb területei az egyetemi oktatók és a gyakorlóiskola pedagógusai szerint?

- A hallgatók, a vezetőtanárok és az oktatók szerint milyen változtatásokra lenne szükség a képzés hatékonyságának növelése érdekében?

\section{A kutatás hipotézisei}

A kutatási kérdések alapján a hipotézisek egyfelől a gyakorlóiskola által kínált tevékenységekhez, másfelől a jelöltek szakmai felkészültségéhez kapcsolódnak.

Hipotézisek a csoportos iskolai gyakorlatok során elvégezendő hallgatói tevékenységekhez kapcsolódóan:

- H1: A csoportos gyakorlatok során a hallgatóknak lehetőségük van az iskola és a tanári professzió megismeréséhez kapcsolódó kutatási feladatokat elvégezésére.

- H2: A hallgatók megítélése szerint a gyakorlatok során elvégezendő kutatási, hospitálási és óratartási feladatok jelentős mértékben segítik saját szakmai fejlődésüket.

- H3: A hallgatók elégedettek a szakvezető szakmai felkészültségével.

Hipotézisek a hallgatók szakmai felkészültségével kapcsolatban:

- H4: A hallgatók saját szaktudományos felkészültségükkel a legelégedettebbek, míg a gyakorlóiskolai tanárok szerint nincs jelentős különbség a 
hallgatók szaktudományos, szakmódszertani és pedagógiai-pszichológiai felkészültsége között.

- H5: Az egyetemi kurzusok a hallgatók és a gyakorlóiskolai tanárok szerint a szaktárgyi tudás területén biztosítják leginkább a hallgatók professzionális felkészülését.

- H6: A csoportos iskolai gyakorlatok tekintetében a hallgatók és a gyakorlóiskolai tanárok véleménye szerint az óratartás biztosítja leginkább a hallgatók tanári professzióra való felkészülését.

Hipotézisek a tanárképzés fejlesztésére vonatkozó elképzeléseket illetően:

- H7: A hallgatók az osztályirányítás és az egyéni tanulási szükségletekkel kapcsolatos kihívások (fegyelmezés, az egyéni bánásmódot igénylő tanulók, szülőkkel való kommunikáció) területein észlelnek leginkább hiányosságokat.

- H8: A pedagógusjelöltek, a vezetőtanárok és az egyetemi oktatók véleménye különbözik tanárképzés fejlesztésére vonatkozó elképzelések terén.

\section{Kutatási stratégia és módszerek}

Jelen összefoglaló alapjául szolgáló kutatás típusa esettanulmány. Golnhofer (2001) értelmezését alapul véve az esettanulmány tárgya egy ún. „tipikus” esetet, az Eszterházy Károly Gyakorlóiskola tanárképzési folyamatban betöltött funkcióját és hatékonyságát vizsgálja. Az esettanulmány során a dokumentumelemzés és a kérdőíves vizsgálat kapta a főszerepet. A dokumentumelemzés az iskolai dokumentumokat (SZMSZ, Pedagógiai program, Házirend, Munkaterv) érintette. A kérdőíves vizsgálatból a hallgatói, az egyetemi oktatói és a pedagógusi kérdőívek jelen részkutatást érintő kérdései kerültek bevonásra. A nyílt kérdésekre adott válaszok elemzése tartalomelemzéssel, nyílt kódolással történt, a kategóriák megbízhatóságát intrakódolás biztosította (vö. Antal, 1976; Sánta, 2015). Az egyváltozós elemzésekhez leíró statisztikai módszereket alkalmaztunk (átlag, szórás, medián, módusz számítása). Az összehasonlító elemzésekhez matematikai statisztikai elemző módszereket alkalmaztunk: vizsgáltuk az egyes (hallgatói, oktatói, pedagógusi) almintákhoz rendelt változók közötti összefüggéseket és az alminták közötti különbségeket az egyes változók tekintetében. 


\section{A dokumentumelemzés eredményei}

Az eredmények bemutatását az iskolai dokumentumok elemzésével kezdem. A résztémámhoz kapcsolódó dokumentumelemzés magába foglalja a gyakorlótanításhoz kapcsolódó útmutatókat (Dudás, 2011; Sándor, 2011), illetve az iskola működéséhez kapcsolódó szabályzatokat, terveket (Házirend, 2016; Munkaterv, 2016/17; Pedagógiai program, 2016; SZMSZ, 2016).

A tanári mesterképzési szakhoz kapcsolódó gyakorlati képzés elvárásait az 15/2006. (IV.3.) OM rendelet 4. számú melléklete szabályozza az alábbiak szerint: „A szakmai gyakorlat célja: a szakképzettséghez kapcsolódó gyakorlati ismeretek (pl. tanórára való felkészülés, óratervezés, óravezetés, tanári szerepkörök, pedagógiai mérések és kísérletek) megszerzése, a munkahely világával való ismerkedés (pl. iskolai élet, iskolavezetés, szülőkkel való kommunikáció), valamint az, hogy a hallgatók későbbi munkájuk hatékonysága érdekében jártasságot szerezzenek a tanitási és tanulási, illetve nevelési folyamatok értékelésében, fejlesztésében és kutatásában a 8.4. pontban foglaltak szerint." (15/2006 OM rendelet)

Az iskola legutoljára 2016-ban jóváhagyott Pedagógiai programjának nyitó része egy olyan mottóval kezdődik Trefort Ágostontól, mely jól tükrözi azt a kettős funkciót, amelyet az iskola zászlajára tűzött. Vagyis egyszerre tölti be közoktatási és felsőoktatási (tanárképzési) funkcióját: „Mintaiskola legyen kettős értelemben: egyrészt, mint állami intézmény a közoktatási teljesitményében legyen minőségi, és kezdeményező a változásokban, másrészt a pedagógusképzésnek legyen gyakorlati mühelye."

Maga a Pedagógiai program a tanulókkal kapcsolatos pedagógiát részletezi, a gyakorlóiskolai funkció jelenségeivel kapcsolatban nem rendelkezik és nem is utal rájuk semmilyen értelemben.

A 2016/17-es munkaterv nem jelenít meg a pedagógusképzéssel kapcsolatos új tevékenységeket, irányokat. A minőségirányítási program részeként, a fő minőségcélok között jelenik meg az intézmény általános megítéléséhez és működéséhez kapcsolódva a partnerekkel való kommunikáció szorosabbá és hatékonyabbá füzése, ám ennek módjait a hallgatókra vonatkozóan nem részletezi a dokumentum.

A Szervezeti és Müködési SAz iskola házirendje gyakorlaton részt vevő hallgatókzabályzat alapadatai között a szakfeladatok ellátásánál jelöli a felsőfokú oktatást, ami köznevelési iskolai gyakorlatok ellátását takarja. A tanárképzésre vonatkozó szabályozások egyedül a munkaköri leírás mintáinál találhatóak, mégpedig a pe- 
dagógus munkakörön belül (speciális megbízások) a szakvezető-nevelési oktatási gyakorlatot vezető pedagógus feladatainak felsorolásánál. Eszerint a szakvezetők általános feladatai közé tartozik a hallgatók tájékoztatása az iskoláról, az intézmény belső és külső kapcsolatrendszeréről, valamint külön felkérés alapján részvétel a blokkszemináriumokon vagy a tanári képesítővizsga bizottságában. A szabályzat itt emeli ki, hogy „a hallgatók elvégzendő feladataira a tanárjelöltekkel szemben támasztott egységes, gyakorlóiskolai követelményrendszerben foglaltak az irányadók" (Szmsz, 2016. 81. o.), azaz az ún. tanítási gyakorlatok leírását tartalmazó Útmutató dokumentumok (Dudás, 2011; Sándor, 2011). A szakvezetők irányítással kapcsolatos feladatai közé a beosztott hallgatói csoportok vezetése tartozik. Kapcsolattartási kötelezettségei vannak továbbá a pedagógia-pszichológia tanszékek oktatóival, amelynek során a feladatok egyeztetésére és a tapasztalatok viszszajelzésére van lehetőség. Szervezési feladatai közé tartozik a hospitálások, óravezetések és mikrotanítások megszervezése és az azokat követő beszélgetések vezetése; az interjúk és kérdőíves vizsgálatok előkészítése és segítése (például osztályok kijelölése); a hallgatói jegyzőkönyvek értékelése. Az ellenőrzési feladatai közé tartozik, hogy a TVSz alapján figyelemmel kíséri és dokumentálja a tanárjelöltek gyakorlóiskolai jelenlétét; a tanórákat követő megbeszélések elemzése, értékelése, de csak a hallgató reflexióját követően; segíti a hallgatói dokumentumok elkészítését, és portfólióba való feltöltését; értékeli a hallgató féléves teljesítményét, és azt elektronikusan rögzíti (SzMSz, 2016).

$\mathrm{Az}$ iskola házirendje a gyakorlaton részt vevő hallgatókra vonatkozó vagy velük kapcsolatos előírásokat nem tartalmaz, csak a bevezetőben említi meg, hogy a hallgatók iskolai tapasztalatainak képi dokumentálása a személyiségi jogok tiszteletben tartásával a gyakorlatok része.

Az iskolában zajló gyakorlati felkészítés célját, módját, értékelését és speciális területeit az Útmutató című dokumentumok (Dudás, 2011; Sándor, 2011) deklarálják, melyek a tanári mesterképzési szakhoz kapcsolódó 15/2006. (IV.3.) OM rendelet előírásai alapján készültek. Az iskola a szakmai gyakorlati képzés célját a következőkben fogalmazza meg: „Célunk annak az elvnek az érvényesitése, hogy a tanári mester képesités megszerzésére irányuló gyakorlati képzés épüljön elméleti és gyakorlati tudásra. A hallgató képes legyen az elsajátított pszichológiai-pedagógiai és szakmódszertani ismereteket az adott korosztály esetén alkalmazni, valamint szakterületi felkészültsége alapján képes legyen a tanulók megismerésére, a tanórán és a 
tanórán kivüli munkában hatékony pedagógiai módszerek alkalmazására" (Sándor, 2016. 3. o.).

$\mathrm{Az}$ iskolai gyakorlatok három típusa jelenik meg a mesterképzésekben (1. táblázat). Az első a Nevelési-oktatási gyakorlat melynek célja, hogy a hallgatók kapcsolatba kerüljenek az iskola belső világával, az iskolai dokumentumokon és saját tapasztalataikon keresztül megismerjék az iskola szerkezetét, döntési mechanizmusait. Lehetőségük legyen a pedagóguspálya teljesebb megismerése, megfigyeljék és értelmezzék a tanulói konfliktusok sajátosságait, valamint képesek legyenek a meglátogatott tanórák reflektív elemzésére. A hallgatók a gyakorlat során dokumentumelemzést, kérdőíves vizsgálatot, mikrotanítást végeznek, interjúkat készítenek és hospitálnak, melyhez a pedagógia és pszichológia tárgyak oktatóitól és a gyakorlóiskola szakvezetőitől kapnak segítséget. A gyakorlat időtartama 45 óra +1 hetes gyakorlóiskolai gyakorlat (Dudás, 2011). Az Iskolai tanítási gyakorlat két ütemben, két szemeszterben történik. A szakmai gyakorlat célja a szaktárgy ismeretanyagának oktatásához (tervezéshez, órairányításhoz és értékeléshez) szükséges tanári kompetenciák fejlesztése. Az első szakmai gyakorlat során a hallgatók heti 3 órában összesen 45 órát töltenek a gyakorlóintézményben és a félév során minimum 2 órát tanítanak csoport előtt. A másik szemeszterben heti 2 órában összesen 30 órás gyakorlaton vesznek részt. Ez kiegészül még egy kéthetes összefüggő gyakorlattal, aminek során a hallgató a hospitálások mellett legfeljebb 11 órát tanít. A gyakorlat közismereti szakképzettségek esetén zárótanítással zárul (Sándor, 2011). Az Összefüggő, egyéni szakmai gyakorlat több elkülöníthető részből tevődik össze. Az Iskolai alaptevékenységek közé tartozik a szakvezetővel közös tanóratervezés, heti 2-5 óra foglalkozásvezetés és a főiskola oktatói által vezetett 3 alkalmas blokkszemináriumon való részvétel. A Tanításon kívüli iskolai tevékenységek keretében a hallgatók tehetséggondozó, tanulást támogató tevékenységek vesznek részt, illetve napközis vagy tanulószobai foglalkozásokat vezetnek. Ezen kívül olyan további tevékenységek közül kell választaniuk, mint például osztályfőnöki tevékenység, iffúságvédelem, támogató, segítő rendszerek, szakmák megismerése, iskolai rendezvényeken való részvétel, szervezés. Az Iskolán kívüli tevékenységek során a hallgatók csoportos látogatást végeznek olyan pedagógusi munkát segítő intézményekben, mint például a Nevelési Tanácsadó vagy a Szakértői Bizottságok. A gyakorlatot az adott szaktárgyhoz tartozó szakvezető tanárok és a hallgató féléves munkáját végigkísérő mentortanárok irányítják és segítik. Az iskolai gyakorlatok tapasztalatait rögzítő dokumentumokat a hallga- 
tóknak portfólióba kell rendezniük (Magyar, 2011). A három gyakorlat közül az Eszterházy Károly Egyetem hallgatói az első kettőt végzik a gyakorlóiskolában.

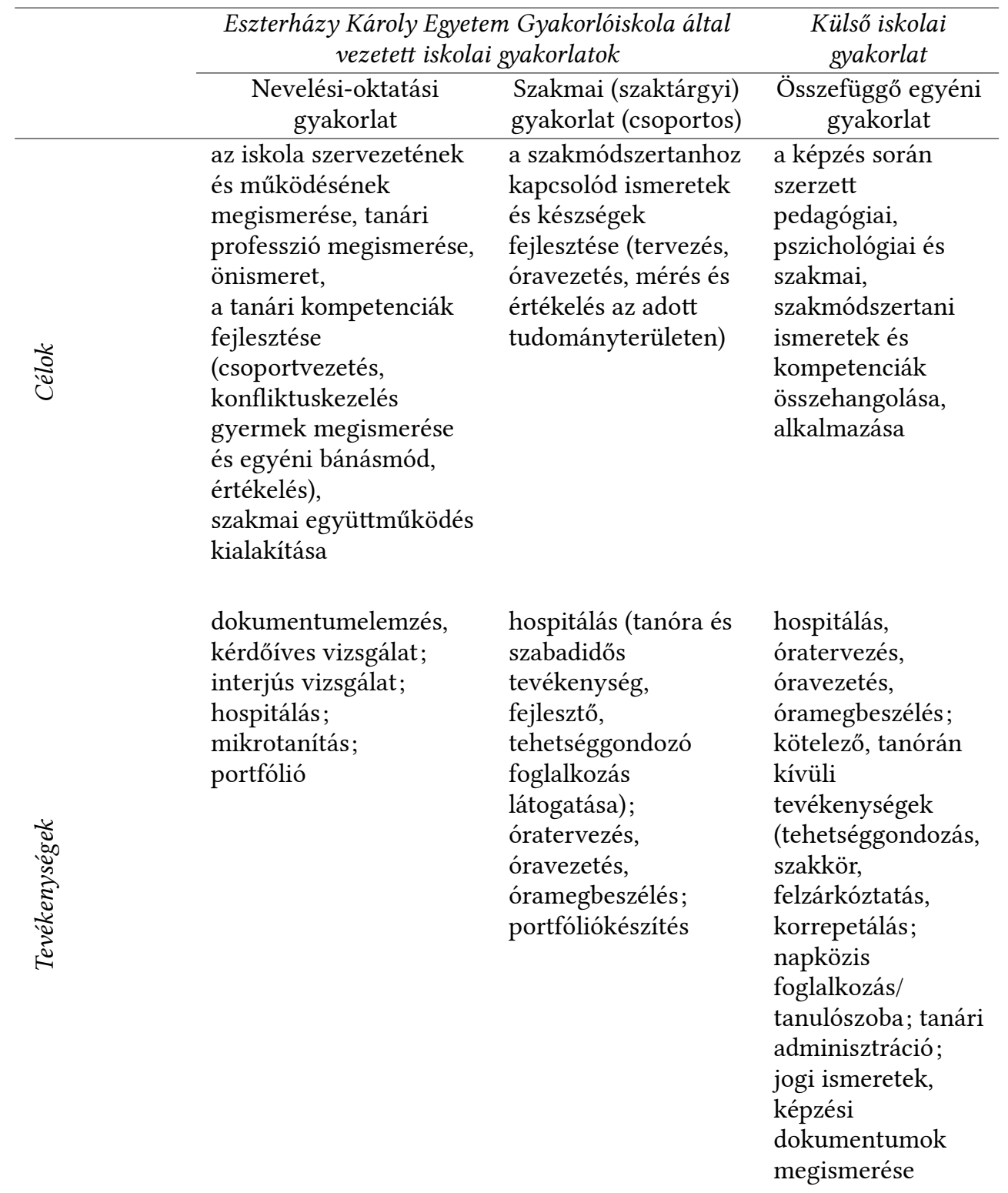


Pedagógusképzés • 18(46), 2019/1-2.

\begin{tabular}{|c|c|c|c|}
\hline 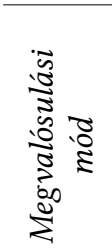 & $\begin{array}{l}\text { csoportos: egy } \\
\text { szakvezető 5-7 } \\
\text { hallgatóval dolgozik }\end{array}$ & $\begin{array}{l}\text { csoportos: egy } \\
\text { szakvetető tanár } \\
\text { maximum } 5 \\
\text { hallgatóval közösen }\end{array}$ & $\begin{array}{l}\text { egyéni (mentor és } \\
\text { szakvezető tanár } \\
\text { irányításával) }\end{array}$ \\
\hline
\end{tabular}

1. táblázat: Az iskolai gyakorlatokat összehasonlító táblázat

\section{A kérdőíves vizsgálat eredményei}

\section{Eredmények a csoportos gyakorlatok során elvégzendő hallgatói tevékenységekkel kapcsolatban}

A visszajelzésekből az derül ki, hogy a hallgatók közel felének volt lehetősége a gyakorlóiskolai kutatási tevékenységekkel kapcsolatos elvárásokat teljesíteni. Habár a gyakorlótanításhoz kapcsolódó Útmutató kötelezően két interjú és egy kérdőíves vizsgálat elvégzését írja elő, a hallgatók átlagosan közepes mértékben jelezték vissza ennek lehetőségét, ami azt jelenti, hogy a megkérdezettek fele tudta csak teljesíteni az elvárásokat (2. táblázat). A kérdés az, hogy ennek a feltételek hiánya vagy hallgatói mulasztás volt-e az oka.

\begin{tabular}{|c|c|c|c|c|c|}
\hline & $N$ & Min. & Max. & Átlag & Szórás \\
\hline Lehetőségem volt interjúk készítésére. & 22 & 1 & 5 & 3,45 & 1,654 \\
\hline $\begin{array}{l}\text { Lehetőségem volt a szaktárgyhoz kapcsolódó helyi } \\
\text { tanterv, tanmenet megismerésére. }\end{array}$ & 21 & 1 & 5 & 3,52 & 1,327 \\
\hline $\begin{array}{l}\text { Megismertem az intézmény rendszerét, főbb doku- } \\
\text { mentumait. }\end{array}$ & 22 & 1 & 5 & 3,55 & 1,184 \\
\hline $\begin{array}{l}\text { Lehetőségem volt az iskolai dokumentumok elemzé- } \\
\text { sére. }\end{array}$ & 22 & 1 & 5 & 3,64 & 1,399 \\
\hline Lehetőségem volt kérdőíves vizsgálat készítésére. & 22 & 1 & 5 & 3,64 & 1,590 \\
\hline
\end{tabular}

2. táblázat: A hallgatók egyetértésének mértéke az intézmény megismerését célzó kutatási lehetőségekre vonatkozóan a csoportos iskolai gyakorlatok során $(\mathrm{N}=22)$

A vizsgálat kiterjedt arra is, hogy a hallgatók, mely gyakorlóiskolában végzett tevékenységet érezték a leghatékonyabbnak. A hallgatói visszajelzések alapján saját professzionális fejlődésükhöz legkiemelkedőbb mértékben az óratartás járult hozzá (3. táblázat). Ez megerősíti a korábbi hazai kutatási eredményeket, amelyek szerint az egész tanárképzés leghatékonyabb részeként az óratartást élik meg a hallgatók (N. Kollár, 2011). Kutatásunkban az óratartást a rangsorban a hospitálásokkal kapcsolatos teendők és a mikrotanítás követte. A legkevésbé átlagosan a kutatással kapcsolatos tevékenységeket (kérdőívkészítés, interjú, dokumentum- 
elemzés) érezték hasznosnak a hallgatók, jóllehet ez utóbbi csoportban a válaszok között óriási szórás mutatkozik. A szórások hátterére az összefüggés-vizsgálatok világítanak rá, amelyek azt mutatják, hogy akiknek lehetőségük volt ezeket a tevékenységeket elvégezni, azok sokkal pozitívabban nyilatkoztak építő jellegükről.

\begin{tabular}{|c|c|c|c|c|c|}
\hline & $N$ & Min. & Max. & Átlag & Szórás \\
\hline Iskolai dokumentumok elemzése & 17 & 1 & 5 & 2,94 & 1,249 \\
\hline $\begin{array}{l}\text { Kérdőíves vizsgálat elvégzése az isko- } \\
\text { lában }\end{array}$ & 14 & 1 & 5 & 3,07 & 1,269 \\
\hline $\begin{array}{l}\text { Interjúk készítése az iskolában dolgozó } \\
\text { kollégákkal }\end{array}$ & 13 & 1 & 5 & 3,15 & 1,463 \\
\hline Portfóliókészítés & 16 & 1 & 5 & 3,50 & 1,265 \\
\hline Hospitálási jegyzőkönyv készítése & 22 & 1 & 5 & 3,73 & 1,162 \\
\hline $\begin{array}{l}\text { Hospitálás tanórán kívüli foglalkozá- } \\
\text { son }\end{array}$ & 15 & 1 & 5 & 4,13 & 1,060 \\
\hline Mikrotanítás & 16 & 2 & 5 & 4,25 & 1,000 \\
\hline $\begin{array}{l}\text { Tanórán kívüli foglalkozások megtar- } \\
\text { tása }\end{array}$ & 10 & 1 & 5 & 4,30 & 1,337 \\
\hline Hospitálásokat követő megbeszélések & 22 & 2 & 5 & 4,45 & ,858 \\
\hline $\begin{array}{l}\text { Hospitálás hallgatótársaim által tar- } \\
\text { tott órákon }\end{array}$ & 22 & 3 & 5 & 4,50 & ,673 \\
\hline Óravázlatok készítése & 22 & 1 & 5 & 4,50 & ,964 \\
\hline Hospitálás vezetőtanárom óráin & 22 & 3 & 5 & 4,55 & ,739 \\
\hline $\begin{array}{l}\text { Megtartott tanórák átbeszélése a veze- } \\
\text { tőtanárral }\end{array}$ & 22 & 2 & 5 & 4,59 & ,796 \\
\hline Tanórák megtartása & 22 & 3 & 5 & 4,73 &, 550 \\
\hline
\end{tabular}

Az óralátogatásokkal kapcsolatos kérdések alapján elmondható, hogy a hallgatók a meglátogatott órák színvonalával teljesen elégedettnek bizonyultak. Továbbá szignifikáns pozitív összefüggés rajzolódott ki a meglátogatott órák színvonala és a szakvezető pedagógiai $(r=578, p=0,005)$, illetve tantárgy-pedagógiai $(r=0,660$, $\mathrm{p}=0,001)$ tudásának megítélése között. 
Pedagógusképzés • 18(46), 2019/1-2.

\begin{tabular}{|c|c|c|c|c|c|}
\hline & $N$ & Min. & Max. & Átlag & Szórás \\
\hline $\begin{array}{l}\text { Elégedett voltam a meglátogatott órák } \\
\text { szakmai színvonalával. }\end{array}$ & 22 & 3 & 5 & 4,50 & 673 \\
\hline $\begin{array}{l}\text { Elégedett voltam a szakvezetőm szak- } \\
\text { módszertani (tantárgypedagógiai) felké- } \\
\text { szültségével. }\end{array}$ & 22 & 2 & 5 & 4,55 & ,858 \\
\hline $\begin{array}{l}\text { Elégedett voltam a szakvezetőm peda- } \\
\text { gógiai felkészültségével. }\end{array}$ & 22 & 2 & 5 & 4,59 & ,796 \\
\hline $\begin{array}{l}\text { Elégedett voltam a szakvezetőm szaktár- } \\
\text { gyához kapcsolódó elméleti felkészült- } \\
\text { sécével }\end{array}$ & 22 & 2 & 5 & 4,77 & 685 \\
\hline
\end{tabular}

4. táblázat: A hallgatók elégedettsége a szakvezetők pedagógiai, szakmódszertani és szaktárgyi felkészültségével kapcsolatban, a meglátogatott órák szakmai színvonalával ( $\mathrm{N}=22$, hallgatói kérdőív 8. kérdés)

\section{Eredmények a hallgatók szakmai felkészültségével kapcsolatban}

\section{Óratervezéssel és szervezéssel összefüggó területek}

Az óratartás hasznosságát erősíti az a tény is, hogy a hallgatók a saját tanári kompetenciák fejlődését az óratervezés (4,73), valamint a szaktárgy oktatásához szükségek készségek fejlődése terén $(4,32)$ érzik leginkább. Valamivel alacsonyabb mértékben, de átlagosan még mindig egyetértés mutatkozik a hallgatók között a tekintetben, hogy a csoportos gyakorlatok során fejlődtek a különböző munkaformák és módszerek alkalmazása $(4,09)$, a pedagógiai értékelés $(4,09)$ és a taneszközök alkalmazása terén is $(4,00)$. A hallgatók az óráik értékelését teljesen reálisnak tartották $(4,5)$ (5. táblázat).

A gyakorlótanításhoz kapcsolódó tárgyi feltételekkel a hallgatók elégedettebbnek bizonyultak (átlag: 4,26), mint az oktatók (átlag: 3,9). A hallgatói visszajelzések alapján a tárgyi feltételekkel való elégedettség szoros összefüggést mutatott a szaktárgy oktatásához kapcsolódó készségek $(\mathrm{r}=0,780, \mathrm{p}=0,000)$, a különböző módszerek alkalmazásának $(\mathrm{r}=890, \mathrm{p}=0,000)$ és a taneszközök alkalmazásának $(\mathrm{r}=0,674, \mathrm{p}=0,001)$ fejlődésével.

\section{Szülőkkel való együttmüködés és osztályfönöki feladatok ellátása}

A hallgatók és az iskolában tanító tanárok egyaránt úgy vélték, hogy sem az egyetem, sem a gyakorlóiskola nem biztosítja a hallgatói kompetenciák fejlődését a szülőkkel való együttműködés terén (5. táblázat és 2. ábra).

A hallgatók 73\%-a úgy érezte, egyáltalán nem, 23\%-a inkább nem fejlődött a szülőkkel való együttműködés terén. Csupán egyetlen (tehetségfejlesztő szakos) hallgató érezte úgy, hogy az egyetemi képzés erre is fókuszált, de ennek ellenére ő 
is csak közepes mértékben érzi ezen a területen saját szakmai fejlődését. A hallgatók véleménye két kivételtől eltekintve egyöntetűnek mutatkozik abban a tekintetben, hogy nem volt lehetőség a szülőkkel való kapcsolatteremtésre (például szülői értekezleten való részvétel) a gyakorlat során.

Szintén egyöntetủen negatív visszajelzések érkeztek az osztályfőnöki feladatokkal kapcsolatos fejlődés terén, habár a hallgatók több mint fele (59\%) részt vett osztályfőnöki órán, 23\%-uk pedig közre is működött a megvalósításban (5. táblázat és 2. ábra).

\section{Tehetséggondozás, felzárkóztatás, differenciálás}

A másik problémás terület az átlagostól eltérő képességek fejlesztése terén, a tehetséggondozás és a felzárkóztatás terén $(2,64)$ mutatkozott. Tehetséggondozó foglalkozáson a hallgatók csupán $18 \%$-a vett részt. Felzárkóztató foglalkozásokon a hallgatók 4,5\%-a vett részt, de ilyen tevékenység megvalósításban 13\%-uk közreműködött. Fejlesztő foglalkozásokon a hallgatók $27 \%$-a vett részt. ${ }^{1}$ Összességében a hallgatók csupán $10 \%$-a, a gyakorlóiskola tanárok pedig már csak 3-4\%-a érezte úgy, hogy a gyakorlóiskola ezeken a területeken biztosítja a hallgatók szakmai fejlődését. Ehhez kapcsolódó szintén problémás terület, de már pozitívabb képet mutat a tanórai differenciálás. A hallgatók válaszai között nagy eltérés mutatkozott a tekintetben, hogy a differenciálás terén mennyire érezték fejlődésüket, de átlagos értelemben közepes mértékben $(3,23)$. Differenciált tanórai foglalkozáson és azok megvalósításában a hallgatók 13,6\%-a vett részt. Ezzel összefüggésben a hallgatók 16\%-a, a tanárok 8\%-a gondolja úgy, hogy a gyakorlóiskola felkészíti erre a feladatra a hallgatókat. Ez az arány meglehetősen alacsony, hiszen a gyermekek megismerése és az egyéni bánásmód terén szerzett tapasztalatok kiemelkedő célként fogalmazódnak meg az Útmutatókban (a tanárok számára pedig a NAT-ban) (5. és 6. táblázat).

\footnotetext{
${ }^{1}$ Noha az Útmutató szerint a szaktárgyi gyakorlat egyik eleme a fejlesztő, illetve tehetséggondozó foglalkozás látogatása kellene, hogy legyen.
} 
Pedagógusképzés • 18(46), 2019/1-2.

\begin{tabular}{l|cc}
\hline & $\begin{array}{c}\text { "Hospitáltam ilyen } \\
\text { alkalmon” }\end{array}$ & $\begin{array}{c}\text { "Részt vettem a } \\
\text { megvalósításában” }\end{array}$ \\
\hline Fogadóóra & $0 \%$ & $0 \%$ \\
Felzárkóztató foglalkozás & $4,5 \%$ & $13,6 \%$ \\
Differenciált tanórai foglalkozás & $13,6 \%$ & $13,6 \%$ \\
Osztályfőnöki óra & $59 \%$ & $22,7 \%$ \\
Fejlesztő foglalkozás & $27,3 \%$ & $4,5 \%$ \\
Szülői értekezlet & $9,1 \%$ & $0 \%$ \\
Tehetséggondozó foglalkozás & $18,2 \%$ & $9,1 \%$
\end{tabular}

5. táblázat: Tanórai és tanórán kívüli tanári feladatok, melyeket látogatott, és amelyek megvalósításában részt vett a hallgató (relatív gyakoriság, $\mathrm{N}=22$, hallgatói kérdőív 10, 11 . kérdés)

\begin{tabular}{|c|c|c|c|c|c|}
\hline & $N$ & Min. & Max. & Átlag & Szórás \\
\hline $\begin{array}{l}\text { Fejlődtem a szülőkkel való együttműködés } \\
\text { terén. }\end{array}$ & 22 & 1 & 3 & 1,32 &, 568 \\
\hline $\begin{array}{l}\text { Fejlődtem az osztályfőnöki feladatok ellá- } \\
\text { tása terén. }\end{array}$ & 22 & 1 & 5 & 1,91 & 1,151 \\
\hline Fejlődtem a tehetséggondozás területén. & 22 & 1 & 5 & 2,64 & 1,255 \\
\hline Fejlődtem a tanulói felzárkóztatás területén & 22 & 1 & 5 & 2,64 & 1,093 \\
\hline $\begin{array}{l}\text { Fejlődtem a tanári munkához kapcsolódó } \\
\text { adminisztrációs feladatok ellátása terén. }\end{array}$ & 22 & 1 & 5 & 2,68 & 1,427 \\
\hline $\begin{array}{l}\text { Megismertem a diákok közötti konfliktu- } \\
\text { sok sajátosságait, okait. }\end{array}$ & 22 & 1 & 5 & 2,82 & 1,296 \\
\hline $\begin{array}{l}\text { Fejlődtem a gyakorlóiskolában dolgozó } \\
\text { kollégákkal való együttműködés terén. }\end{array}$ & 22 & 1 & 5 & 2,86 & 1,521 \\
\hline $\begin{array}{l}\text { Fejlődtem a kooperatív módszerek alkal- } \\
\text { mazása terén. }\end{array}$ & 22 & 1 & 5 & 3,14 & 1,283 \\
\hline Fejlődtem tanórai differenciálás terén. & 22 & 1 & 5 & 3,23 & 1,193 \\
\hline Fejlődtem iskolai konfliktuskezelés terén. & 22 & 1 & 5 & 3,27 & 1,162 \\
\hline $\begin{array}{l}\text { Megismertem azokat a főbb szakmai, mód- } \\
\text { szertani lehetőségeket, amelyekkel a tanu- } \\
\text { lók egyéni szükségletei feltárhatóak. }\end{array}$ & 22 & 1 & 5 & 3,77 & 1,193 \\
\hline $\begin{array}{l}\text { Fejlődtem az osztálytermi problémahelyze- } \\
\text { tek megoldása terén }\end{array}$ & 22 & 1 & 5 & 3,77 & 1,270 \\
\hline $\begin{array}{l}\text { Fejlődtem a különböző taneszközök alkal- } \\
\text { mazása terén. }\end{array}$ & 22 & 2 & 5 & 4,00 & ,976 \\
\hline $\begin{array}{l}\text { Fejlődtem a különböző módszerek alkalma- } \\
\text { zása terén. }\end{array}$ & 22 & 2 & 5 & 4,09 & 1,065 \\
\hline Fejlődtem a pedagógiai értékelés terén & 22 & 1 & 5 & 4,09 & 1,151 \\
\hline $\begin{array}{l}\text { Fejlődtem a különböző munkaformák (pá- } \\
\text { ros, egyéni, csoportos, frontális) alkalma- } \\
\text { zása terén. }\end{array}$ & 22 & 2 & 5 & 4,09 & ,921 \\
\hline $\begin{array}{l}\text { Elégedett voltam a gyakorló tanításhoz } \\
\text { kapcsolódó tárgyi feltételekkel. }\end{array}$ & 22 & 2 & 5 & 4,14 & ,941 \\
\hline $\begin{array}{l}\text { Fejlődtek a szaktárgy oktatásához kapcso- } \\
\text { lódó készségeim. }\end{array}$ & 22 & 2 & 5 & 4,32 & 1,041 \\
\hline
\end{tabular}


Lehetőségem volt a szaktárgy tanításához kapcsolódó módszerek, eszközök megismerésére.

Az óráim értékelését reálisnak tartottam.

Fejlődtem az óratervezés terén.

$\begin{array}{ccccc}22 & 1 & 5 & 4,50 & 1,012 \\ & & & & \\ 22 & 1 & 5 & 4,50 & , 964 \\ 22 & 2 & 5 & 4,73 & , 703 \\ \text { sükre vonatkozó elégedettsége az egyes } \\ \text { hallgatói kérdőív, 8. kérdés) }\end{array}$

Fegyelmezés és konfliktuskezelés

A hallgatók megítélése alapján a diákok közötti konfliktusok sajátosságainak megismerése $(2,86)$, valamint az iskolai konfliktusok kezeléshez kapcsolódó szakmai fejlődés $(3,45)$ átlagosan közepes mértékben valósult meg (6. táblázat). A tanórai problémamegoldás terén már pozitívabb válaszok születtek $(3,77)$. A hallgatók szintén hasonló mértékben érezték, hogy fegyelmezési problémák terén számíthattak vezetőtanárukra (3,79). Érdekes, hogy míg a hallgatók 47\%-a érzi úgy, hogy a gyakorlóiskola a tanórai fegyelmezés területén biztosítja a fejlódést, a tanárok csupán 6\%-a gondolja ugyanezt (2. ábra).

A hallgatók felkészültségének megítélését az elméleti felkészítés három pillére (szaktudomány, szakmódszertan, pedagógiai-pszichológia) alapján a kutatás ötfokú attitűdskálával is vizsgálta. A vezetőtanárok és a hallgatók véleménye megegyezett a tekintetben, hogy a jelöltek melyik téren a leginkább és melyik téren a legkevésbé felkészültek (7. táblázat). Ugyanakkor az is látható, hogy a vezetőtanárok sokkal kritikusabbnak tűnek a hallgatók felkészültségét illetően az egyes területek mentén. A legnagyobb különbség éppen a tantárgypedagógiai felkészültség megítélése terén mutatkozott a két csoport között.

Habár a jelöltek pszochológiai felkészültségével a legelégedettebbek, a nyílt kérdésekre adott válaszokból kiderül, hogy a vezetőtanárok mit hiányolnak ezen a területen:

- „A tanítási órákon adódó nevelési helyzetekkel gyakran nem tudnak mit kezdeni, nem tudnak fegyelmezni, sokszor nehezen fejezik ki magukat, nem tudnak kérdéseket fogalmazni, és megfelelő hangerővel beszélni."

- „Igyekvők, de gyakorlati kérdésekben tapasztalatlanok, bizonytalanok."

- „A megszerzett elméleti tudást a vizsga után hamar elfelejtik.”

- „Kevés a gyerekek körében szerzett gyakorlati tapasztalatuk.”

- „Szegényes a pedagógiai eszköztáruk.”.

A jelöltek szaktárgyi tudása tekintetében a vezetőtanárok szerint a hallgatók nem az iskolai gyakorlathoz (általános és középiskolai tananyaghoz) kapcsolódó 
elméleti képzést kapják az egyetemen, ezért sok a szaktárgyi tévedésük a tanórákon:

- „Az egyetemi képzésben megszerzett elméleti tudást nem mindig tudják alkalmazni a tanítás gyakorlatában és közel hozni a gyerekekhez úgy, hogy az érdekes és érthető legyen."

- „Sokszor először meg kell tanítani a hallgatónak az általa tanítandó anyagot, és csak utána lehet beengedni az osztályokba."

A jelöltek szakmai felkészültségének megítélése a tantárgypedagógia terén a legalacsonyabb. A vezetőtanárok szerint ennek egyik oka, hogy az egyetemi tantárgypedagógiai tanulmányaik előtt már tanítaniuk kell:

- „A szinkronicitás hiánya miatt nincsenek birtokában a még előzetesen elsajátítható tudásnak sem.”

- „A tanítási gyakorlat megkezdése előtt a hallgatók legfeljebb egy önálló tervezetet készítenek, a vizsgára megtanult elméleti anyag is már többnyire feledésbe merült."

\begin{tabular}{l|cccc}
\hline & \multicolumn{3}{|c}{$\begin{array}{c}\text { Vezetótanárok } \\
(N=29)\end{array}$} & \multicolumn{2}{c}{ Hallgatók (saját) $(N=22)$} \\
& Átlag & Szórás & Átlag & Szórás \\
\hline $\begin{array}{l}\text { A hallgatók tantárgypedagógiai } \\
\text { felkészültsége }\end{array}$ & 3,36 & 1,026 & 3,95 & 0,848 \\
$\begin{array}{l}\text { A hallgatók szaktárgyi (tudományos) } \\
\text { felkészültsége }\end{array}$ & 3,6 & 0,724 & 4,05 & 0,911 \\
$\begin{array}{l}\text { A hallgatók pedagógiai-pszichológiai } \\
\text { felkészültsége }\end{array}$ & 3,72 & 0,591 & 4,11 & 0,963
\end{tabular}

7. táblázat: A hallgatók tanári professzióval kapcsolatos felkészültségének megítélése a pedagógusok és a hallgatók szerint $(\mathrm{N}=29 ; \mathrm{N}=22)$

Az egyetem és a gyakorlóiskola szerepe a hallgatók professzionális felkészítését illetően

A listából 19 választási lehetőség közül, legfeljebb 5 kategóriát megjelölve kellett a mintákban szereplő alanyoknak kiválasztaniuk, hogy az egyetem, illetve a gyakorlóiskola mely területeken támogatja leginkább a tanári professzióra való felkészülést.

A hallgatók visszajelzéséből az derül ki, hogy a gyakorlóiskola az óratervezéssel, vezetéssel, értékeléssel összefüggő kompetenciák fejlesztését biztosítja leginkább. Az egyetemi kurzusok a tanári professzióval kapcsolatos teoretikus tudást biztosítják leginkább (munkaformák, szaktárgyi tudás, általános pedagógiai és pszichológiai tudás, reflektivitás). (1. ábra) 


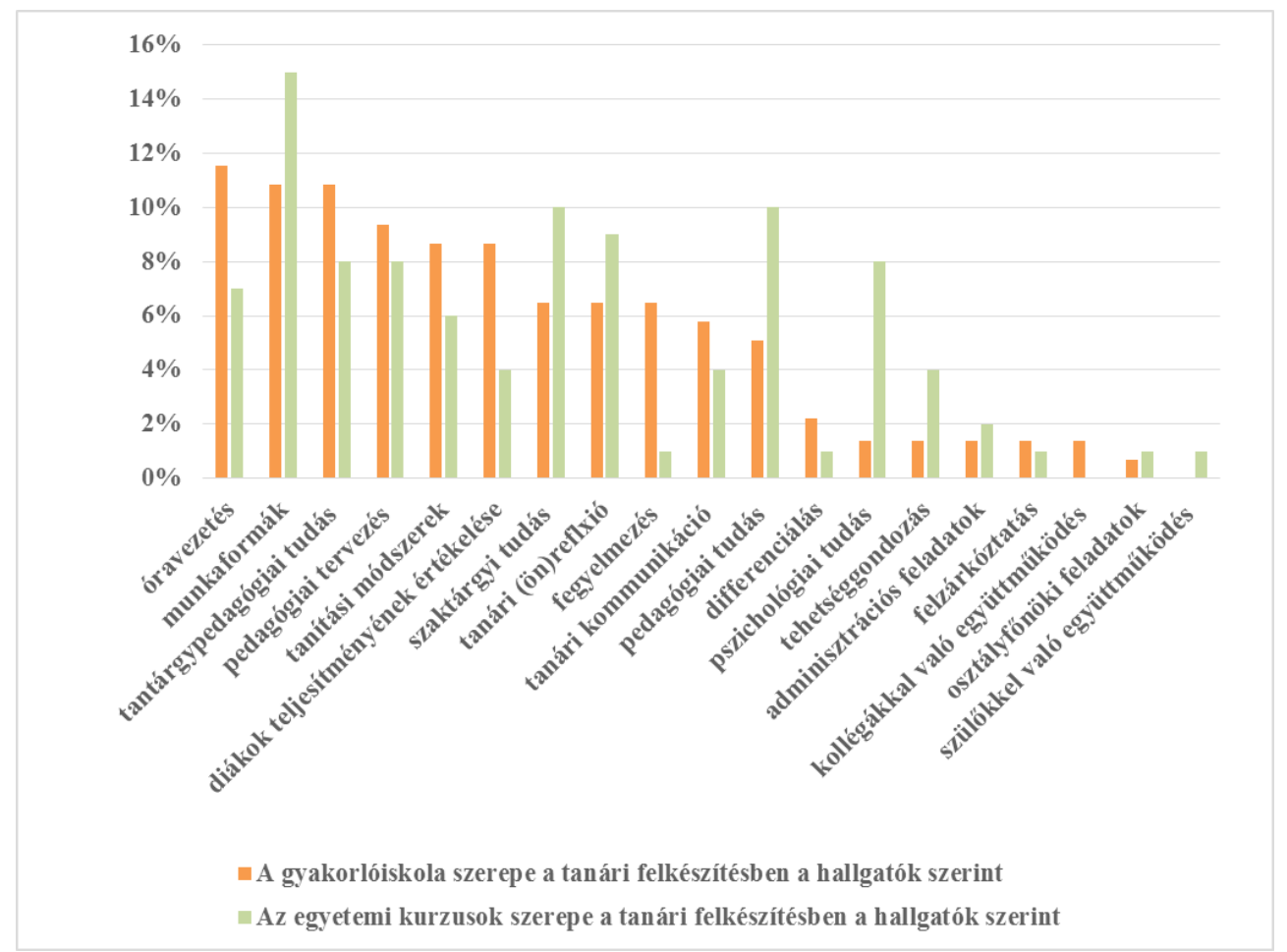

1. ábra: A gyakorlóiskola és az egyetemi kurzusok szerepe a tanári felkészítésben a hallgatók véleménye alapján (relatív gyakoriság, $\mathrm{N}=22$ )

A gyakorlóiskolában tanító tanárok és a hallgatók eltérőképpen vélekednek az egyetem és gyakorlóiskola által nyújtott felkészítésről az egyes területeket illetően. Az egyetemi kurzusok a hallgatók szerint a sokszínú munkaformák megismerése terén készítik fel őket leginkább a tanári professzióra, míg az oktatók szerint az intézmény inkább a szaktárgyi, illetve a pszichológiai-pedagógiai tudás terén biztosítja számukra a legtöbbet (2. ábra). 


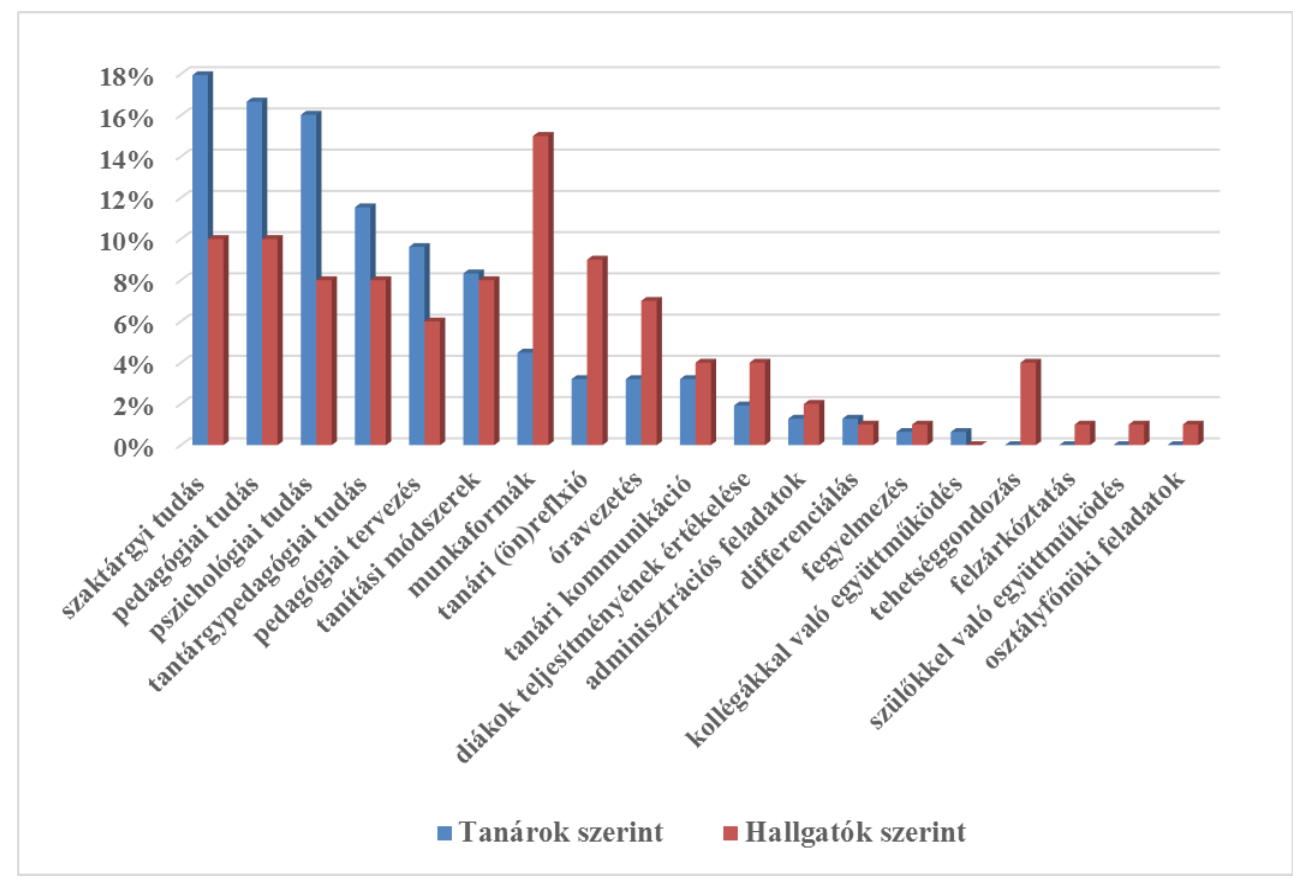

2. ábra: Az egyetemi kurzusok szerepe a tanári professzióra való felkészítés egyes területeit illetően a pedagógusok és a hallgatók szerint (relatív gyakoriság: hallgató: $\mathrm{N}=22$; pedagógus: $\mathrm{N}=102)$

A hallgatók és a gyakorlóiskolában tanító tanárok véleménye megegyezett abban, hogy az egyetemi kurzusok jelentősen hozzájárulnak a szaktárgyi, illetve pszichológiai-pedagógiai tudás bővítéséhez, bár a tanárok szerint ez sokkal dominánsabb, mint ahogyan a hallgatók gondolták. A hallgatók szerint azonban mindezek előtt sokkal jelentősebbek a különböző munkaformákról szerzett ismeretek, míg e tekintetben a tanárok igen lebecsülték az egyetemi képzés hatását. Markáns különbség rajzolódik ki továbbá a tanári önreflexió és az óravezetés terén, amelyeket a hallgatók sokkal hangsúlyosabban észleltek a szemináriumokon, mint azt a tanárok gondolták.

A gyakorlóiskola tanári felkészítésben betöltött szerepével kapcsolatban is mutatkoztak eltérések a két csoport között. Az óratervezés, illetve a tantárgypedagógiai tudás mindkét mintánál a legmagasabb arányban került kiválasztásra a kategóriák közül (3. ábra). A hallgatóknál ezek mellé még a munkaformák kerültek, míg a tanárok a tanítási módszerek terén érezték az iskolai gyakorlatok hatékonyságát. Érdekes módon a vezetőtanárok nem érzékelték, hogy a hallgatók saját megítélésük szerint jelentősen fejlődnek a diákok teljesítményének értékelése te- 
rén. A tanárok ehhez hasonlóan a fegyelmezés terén is alulbecsülték az iskolai gyakorlatok hatását.

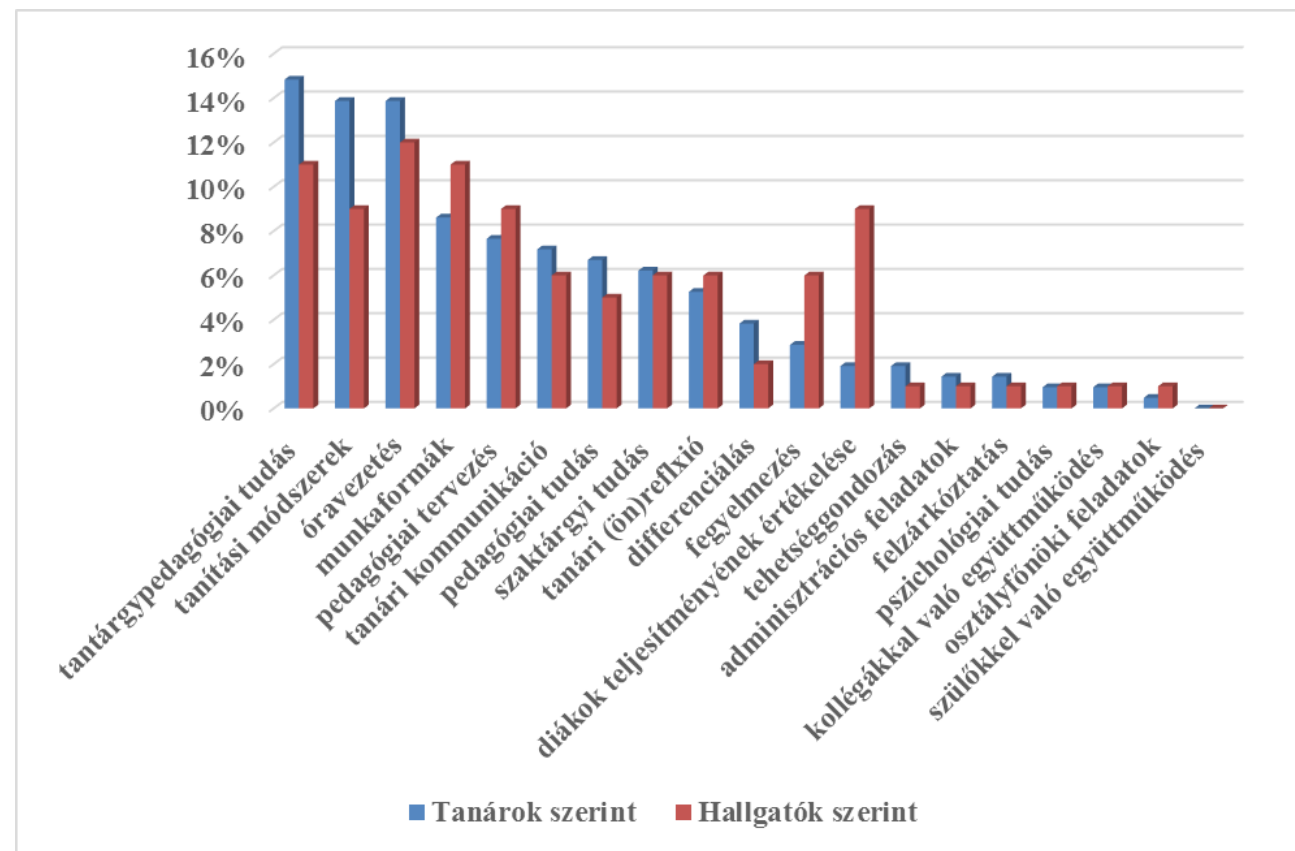

3. ábra: A gyakorlóiskola szerepe a tanári professzióra való felkészítés egyes területeit illetően a pedagógusok és a hallgatók szerint (relatív gyakoriság: hallgatók: $\mathrm{N}=22$, pedagógus: $\mathrm{N}=102$ )

\section{Az iskolai gyakorlatra vonatkozó fejlesztési javaslatok}

A kutatás során a nyílt kérdésre adott válaszokból kiderült, hogy a hallgatók és az oktatók az iskolai gyakorlatok hatékonyságának növelése érdekében milyen változtatásokat javasolnának.

Az iskolai gyakorlat fejlesztésére vonatkozó hallgatói javaslatok egy jelentős része a szaktárgyi hospitálások számának emelésére vonatkozott. A hallgatók több (akár különböző tanárok által tartott) saját szakhoz kapcsolódó órát szeretnének megtekinteni. Az igények másik jelentős része a kihívást jelentő osztálytermi helyzetek kezelésére való hatékonyabb felkészítésre vonatkozott:

- „Esetmegbeszélések a tanítási gyakorlat előtt.”

- „Jó lenne helyzetgyakorlatokat csinálni és megnézni, mi a helyes reakció egy-egy konfliktusra." 
- „Több szélsőséges esettel kellene találkoznunk, a gyakorlatban is átélni a differenciálás módszereit, az egyéni bánásmódot igénylő tanulókkal való foglalkozást."

- „Adott esetek megbeszélése, különböző megoldási lehetőségek mérlegelésével."

A jelöltek szerint sokat segítene az iskolai gyakorlatokra való felkészülésben, ha nem kellene a gyakorlatokkal párhuzamosan az egyetemi kurzusokat is látogatni, azokon teljesíteni, illetve azt az időt a felkészülés vagy az iskolában töltött idő javára lehetne fordítani:

- „Véleményem szerint hatékonyabb lenne, ha a gyakorlat ideje alatt nem kellene az egyetemre órákra menni, csak a gyakorlatra koncentrálnánk."

- „Az egyetemi előadások csökkentése az órákra való felkészülés és több gyakorló tanítás javára."

- „Rugalmasság a többi egyetemi órát tartó tanártól.”

Felmerült annak igénye továbbá, hogy jó lenne, ha minél többféle órát, tanulócsoportot ismerhetnének meg a hallgatók („Több óra tartása és különböző osztályokban - különböző korosztályokban.”, „Minél több tanulói csoportot ismerhessünk meg."), ugyanakkor arra is jelentős igény mutatkozott, hogy egy osztályt, csoportot jobban megismerhessen a jelölt („Egy adott osztállyal többet foglalkozni.”). A vezetőtanárok szerint az iskolai gyakorlat egyértelműen hatékonyabb lenne, ha a jelöltek több időt tölthetnének a gyakorló iskolában, több hospitálással és óratartással:

- „Több időt kellene a gyakorlóiskolában tölteni. Az első időszakban csak mint »szemlélődő «"

- „A hallgatók hosszabb tanítási gyakorlatot végeznének.”

- „Tapasztaljanak, töltsenek minél több gyakorlati órát a gyerekek között.”

- „Több tanítási lehetőséget adnék a hallgatóknak.”

- „Több gyakorlatra van a hallgatóknak szüksége. Ez nem elegendő.”

Többen úgy érzik, hogy a jelöltek elméleti felkészítése hiányos („A hallgatók szakmai és módszertani felkészítése rendkívül hiányos.”, „Az egyetemi képzés túlzottan elméleti.”). Ezért ehhez kapcsolódóan többen fogalmaztak meg javaslatokat:

- „A tanítási gyakorlatot pedig csak a tantárgypedagógiai ismeretek elsajátítása után alkalmaznám." 
- „A módszertani ismeretek megszerzésének keretében gyakorolják a tervezet, illetve vázlat készítését konkrét iskolai tananyagra vonatkoztatva, hogy amikor a gyakorló iskolába kerülnek, ne okozzon ekkora nehézséget az elkészítése.".

Néhányan a szakvezetők bevonását javasolták a szakmódszertan oktatásába.

Az egyetemi szakmódszertanos oktatók leginkább a különböző intézményekben dolgozó kollégák közös gondolkodását, közös munkáját hiányolják:

- „Közös gondolkodás a pedagógia-pszichológia és a szakmódszertani, tanári szakmai tárgyak oktatói között.”

- „Az egyetemi oktatás és a gyakorlóiskolai gyakorlatok közötti kapcsolat erősítésére. Az „elméletet” oktató és a gyakorlatot vezető tanár munkájának összehangolása, párbeszéd erősítése, műhelyek szervezése, ahol kötetlenebb formában lehet egyes kérdésekről beszélni."

A hallgatók gyakorlóiskolába való minél hamarabbi és minél aktívabb részvételét az egyetemi oktatók is támogatják:

- „Több és minél alacsonyabb évfolyamon elkezdett iskolai gyakorlat, nemcsak a gyakorló iskolában.”

- „Minél hamarabb kimenni a gyerekek közé.”

Emellett többekben felmerült, hogy a jelölteknek lehetőséget kellene adni, hogy több vezetőtanárnál is hospitáljanak.

\section{Az eredmények értékelése}

\section{Hipotézisek a csoportos iskolai gyakorlatok során elvégzendö hallgatói tevékenységekkel kapcsolatban}

- H1: A csoportos gyakorlatok során a hallgatóknak lehetőségük van az iskola és a tanári professzió megismeréséhez kapcsolódó kutatási feladatok elvégezésére.

Az iskola és a tanári professzió megismeréséhez kapcsolódó kutatási feladatok (dokumentumelemzés, kérdőíves és interjús vizsgálat, hospitálás és jegyzőkönyvvezetés) elvégezésére a feltételezésünkkel ellentétben nem mindig volt lehetőségük a hallgatóknak. Az adatok alapján az nem derül ki, hogy ennek oka a feltételek hiányában vagy valamiféle hallgatói mulasztásban keresendő. Szükséges lenne mielőbb feltárni a probléma hátterét, mert azon hallgatók, akik teljesítették ezen 
követelményeket, egyértelműen érzékelték a feladatok fejlesztő hatását szakmai fejlődésükben.

- H2: A hallgatók megitélése szerint, a gyakorlatok során elvégzendő kutatási, hospitálási és óratartási feladatok jelentôs mértékben segítik saját szakmai fejlődésüket.

Az adatok alapján a hallgatók professzionális fejlődéséhez a hallgatók szerint legkiemelkedőbb mértékben az óratartás járult hozzá. A kutatási tevékenységekkel (kérdőívkészítés, interjú, dokumentumelemzés) összefüggő elégedettség mértéke jelentősen összefüggött a kutatás elvégzésének lehetőségével. Az adatokból úgy tűnik, hogy csak minden második hallgatónak volt erre lehetősége, ám ennek oka nem egyértelmű. A probléma okának feltárása azért is szükségszerű, mert azon hallgatók, akik tudták teljesíteni az intézmény működésével kapcsolatos kutatási követelményeket, egyértelműen érzékelték a feladatok fejlesztő hatását.

- H3: A hallgatók elégedettek a szakvezető szakmai felkészültségével.

A hallgatók elégedettek voltak a hospitált tanórák színvonalával. Továbbá fontos összefüggésként kirajzolódott az is, hogy a meglátogatott órák színvonalának megítélése az adatok alapján szorosan összefügg a szakvezető pedagógiai, illetve tantárgy-pedagógiai tudásának megítélésével.

\section{Hipotézisek a hallgatók szakmai felkészültségével kapcsolatban}

- H4: A hallgatók saját szaktudományos felkészültségükkel a legelégedettebbek, míg a gyakorlóiskolai tanárok szerint nincs jelentős különbség a hallgatók szaktudományos, szakmódszertani, és pedagógiai-pszichológiai felkészültsége között.

A hallgatói felkészültséggel kapcsolatos hipotézisek kis mértékben igazolódtak be. A hallgatók és gyakorlóiskolai tanárok egyaránt a hallgatók pedagógiai-pszichológiai felkészültségét érezték a legerőteljesebbnek, habár a vezetőtanárok számos hiányosságot megfogalmaztak ezen a területen is. A további sorrend tekintetében is megegyezés látszik kirajzolódni a két csoport között. A jelöltek szaktárgyi tudását illetően is érkeztek észrevételek a vezetőtanároktól, úgy észlelik, hogy az egyetemen nem azok a szaktárgyi ismeretek kerülnek előtérbe, melyekre a hallgatóknak a közoktatásban betöltött szerepük révén szükségük lesz. A hipoté- 
zis abban az értelemben beigazolódni látszott, hogy valóban a hallgatók tantárgypedagógiai tudása terén mutatkoznak a legnagyobb hiányosságok. Ennek oka a vezetőtanárok szerint, hogy nincs összehangolva az egyetemi képzés ütemezése a gyakorlótanítással, így gyakran előbb tanítanak a jelöltek, semmint részt vettek volna a szakmódszertani kurzuson.

- H5: Az egyetemi kurzusok a hallgatók és a gyakorlóiskolai tanárok szerint a szaktárgyi tudás területén biztositják leginkább a hallgatók professzionális felkészülését.

Ez a feltételezés beigazolódott azzal a kiegészítéssel, hogy a hallgatók és a mindezek elé.vezetőtanárok szerint az egyetemi képzés a szaktárgyi tudás mellett a pedagógiai és pszichológiai tudás bővitésébe is kiemelkedő szerepet játszik. A két csoport véleménye között azonban különbség mutatkozott a tekintetben, hogy a hallgatók a különböző munkaformák megismerését emelték mindezek fölé. A gyakorlóiskolai vezetőtanárok egyáltalán nem érzékelik, hogy az egyetemi kurzusok hatást gyakorlónak ez utóbbi területen, ugyanígy lebecsülik a szemináriumok szerepét a tanári (ön)reflexió terén.

- H6: A csoportos iskolai gyakorlatok tekintetében a hallgatók és a gyakorlóiskolai tanárok véleménye szerint az óratartás biztosítja leginkább a hallgatók tanári professzióra való felkészülését.

Ez a feltételezés is beigazolódott annyi kiegészítéssel, hogy mindkét csoport a szakmódszertan, valamint a tanítási módszerek és munkaformák területén is érzékeli a gyakorlóiskola fejlesztő hatását. Az óratartáshoz kapcsolódó tárgyi feltételekkel a hallgatók elégedettebbnek bizonyultak, mint az oktatók. A hallgatói viszszajelzések alapján a tárgyi feltételekkel való elégedettség szoros összefüggést mutatott a szaktárgy oktatásához kapcsolódó készségek, a különböző módszerek alkalmazásának és a taneszközök alkalmazásának fejlődésével. Éppen ezért fontos feladat a tárgyi feltételekben mutatkozó hiányosságok azonosítása és mielőbbi pótlása. 


\section{Hipotézisek a tanárképzés fejlesztésére vonatkozó elképzeléseket illetöen}

- H7: A hallgatók az osztályirányítás és az egyéni tanulási szükségletekkel kapcsolatos kihivások (fegyelmezés, az egyéni bánásmódot igénylő tanulók, szülőkkel való kommunikáció) területein észlelnek leginkább hiányosságokat.

A szakirodalmi előzményekre alapozott hipotézis beigazolódott. A hallgatók szerint a tanári professzióra való felkészülést/felkészítést a képzés a szülőkkel való kapcsolatteremtés területén biztosította legkevésbé a gyakorlóiskola a kutatás szerint. A szülőkkel való kommunikáció megfigyelésére (például szülői értekezlet, fogadóóra), a kapcsolat kialakításához és irányításához kapcsolódó saját kompetenciák fejlesztésére a gyakorlat során a hallgatóknak nem volt lehetőségük.

Az állításokra vonatkozó átlagértékek azt mutatták, hogy a hallgatók az egyéni bánásmódot igénylő tanulók csoportos keretek között történő tanulási tevékenységének megszervezéséhez szükséges saját pedagógiai kompetenciák (differenciálás, felzárkóztatás, tehetséggondozás) fejlỏdését csak közepes mértékben érzékelték átlagos értelemben a hallgatók az iskolai gyakorlat során. Ezt a tényt erősíti, hogy ezen területek azok többek között, amelyekre a hallgatók és a tanárok egyöntetű véleménye alapján az egyetemi kurzusok és a csoportos iskolai gyakorlatok legkevésbé biztosítják a felkészülést.

Az osztálytermi konfliktuskezeléssel kapcsolatos kompetenciák fejlődését az iskolai gyakorlatok közepes mértékben ugyan biztosítják a hallgatók szerint, azonban a nyílt kérdésekből kiderült, hogy a jelöltek hiányolják a konkrét esetekre, konfliktuskezelő stratégiákra vonatkozó megbeszéléseket.

- H8: A pedagógusjelöltek, a vezetótanárok és az egyetemi oktatók véleménye különbözik a tanárképzés fejlesztésére vonatkozó elképzelésekkel kapcsolatban.

A hipotézist nyílt kérdéssel vizsgáltuk, és a felvetés igazolódott. A hallgatók a jelenleginél sokkal gyakorlatiasabb képzést igényelnek. Egyrészt az egyetemen folyó szakaszban is több esetmegbeszélést és helyzetgyakorlatot tudnának elképzelni, másrészt és különösképpen a tanítási gyakorlat óraszámának növelésében látják a fejlesztés fó lehetőségét. Kiemelték azt is, hogy nemcsak a tanítás, de a hospitálás szempontjából is fontos lenne ez, és lehetőleg minél változatosabb kontextusban, hogy a hallgatók többféle csoporttal, módszerrel, tanítási stílussal talál- 
kozhassanak. A hipotézishez hozzátartozik, hogy a hallgatókon kívül a vezetőtanárok és a szakmódszertanos oktatók is egyöntetűen ezen az állásponton voltak.

Az egyetemi oktatók legerőteljesebben a szakmai együttműködés erősítésével kapcsolatban fogalmaztak meg igényeket, mind saját intézményi közeg, mind a képző és a gyakorlóhely kapcsolata tekintetében közös gondolkodás, közös órák vagy szakmai mühelyek keretében. Utaltak arra a szakirodalmi adatokkal is igazolt tagoltságra is, ami a szaktárgyi-pedagógiai/pszichológiai-szakmódszertani tantervi hálók mozaikszerűségére vonatkozik, és összefügg a szakmai együttműködés hiányával. Az oktatók is úgy vélik továbbá, hogy sokkal több iskolai gyakorlatra lenne szükségük a hallgatóknak.

A válaszokból kiderült, hogy a vezetőtanárok alapvetően a tantervi struktúra optimalizálását igényelnék jelentősen, annak érdekében, hogy a jelöltek a gyakorlatokat megfelelő stúdiumok elvégzéséhez kapcsolva vagy azt követően, szakmailag felkészülve végezhessék. Többen úgy érzik, hogy a hallgatóknak alaposabb elméleti felkészítésre lenne szükségük. Feltételezésemmel ellentétben ugyanakkor, az egyetemi oktatók körében fogalmazódtak meg erőteljesebben szakmai együttműködés erősítésére vonatkozó igények.

\section{Összegzés}

A kutatás célja volt, hogy az Eszterházy Károly Egyetem gyakorlóiskolához kapcsolódó esettanulmányon keresztül megvizsgálja a pedagóguspályát választó hallgatók képzéshez kapcsolódó elégedettségét. Az esettanulmány eredményeképpen kiderült, hogy még számos olyan, nemzetközi és hazai szakirodalmi adatok által is jelzett hiányossága van a képzésnek, amelyeknek kiküszöbölésével hatékonyabb felkészítést lehetne biztosítani a pedagóguspályát választó hallgatók számára. Az is kirajzolódott, hogy a lehetséges fejlesztési irányok összekapcsolódnak a szakmai fejlesztő iskolával szemben támasztott elvárásokkal is.

A kutatási eredmények igazolták, hogy a gyakorlóiskola kiemelkedő mértékben biztosítja a szaktárgy oktatásához kapcsolódó készségek fejlődését, beleértve a szaktárgyhoz kapcsolódó tervezési és értékelési folyamatokat, valamint a szaktárgy tanításához kapcsolódó módszerek, eszközök megismerését és kipróbálását. A meglátogatott órák színvonalával és a vezetőtanárok szakmai felkészültségével a hallgatók nagymértékben elégedettek.

A kutatás során azonban az is kiderült, hogy az intézmény által kitűzött, és a hallgatók professzionális felkészítésére fókuszáló célok nem minden tekintetben 
tudnak megvalósulni a gyakorlatban. Ezen hiányosságok egy kisebb csoportja vélhetően csupán intézményi szintủ probléma, másik (nagyobb) csoportja azonban (a rendelkezésre álló hazai és nemzetközi kutatási adatok alapján) rendszerszintű problémákat takar, mert olyan, a gyakorlóintézmények széles körében megjelenő problémákra irányítja a figyelmet, amelyeket a tanárképzéshez kapcsolódó, korábbi szakirodalmi adatok is jeleztek (N. Kollár, 2008; Jancsák, 2012).

Az egri esettanulmány eredményei is alátámasztják, hogy a hallgatók legkevésbé a fegyelmezés, az egyéni bánásmódot igénylő tanulók és a szülői kommunikáció terén érezik eredményesnek szakmai fejlődésüket a gyakorlótanítás során. Ezek tehát rendszerszintű tendenciák, ugyanakkor a gyakorlóiskoláknak fontos lenne átgondolniuk, mit tehetnek annak érdekében, hogy helyi szinten csökkentsék a probléma mértékét.

Kutatásunk alapján elmondható, hogy a fegyelmezéshez kapcsolódó stratégák, módszerek átbeszélésére nagy igény mutatkozik a hallgatók felől akár tanóra előtti vagy tanórát követő esetelemzések keretében. Valószínűleg az egyéni összefüggő, külső iskolai gyakorlat során egy picit több magabiztosságot szerezhetnek ezeken a területeken a hallgatók, de fontos lenne, hogy a képzés minden szintjén kapjanak mankókat, lássanak jó gyakorlatokat.

A hallgatókkal együtt a vezetőtanárok is egyöntetűen jelezték, hogy sem az egyetem, sem a gyakorlóiskola nem biztosítja a hallgatói kompetenciák fejlődését a szülőkkel való együttműködés terén. Pedig fontos lenne, hogy a családokkal való pozitív és erős kapcsolat kialakításának módjait és lehetőségeit minél előbb megtapasztalják a hallgatók is. Annál is inkább, mert számos hazai és nemzetközi kutatás bizonyította, hogy az iskola és a család pozitív kapcsolata hatással van a gyermekek iskolával szembeni attitűdjére és tanulmányi teljesítményére, illetve számos későbbi probléma megelőzhető ezáltal (Bordács - Lázár, 2002; Ligeti Márton, 2002; Polyák - Sófalvy, 2008; F. Lassú - Podráczky - Glauber - Perlusz Marton, 2012). Különösen fontos ennek az együttmüködésnek a megteremtése és erősítése az egyéni bánásmódot igénylő tanulók esetében. Ugyanakkor a visszajelzések alapján a szakvezetők feladata sem egyszerű, ha szeretnék a hallgatókat bevonni ennek a kapcsolatnak az alakulásába. Tapasztalatuk szerint komoly nehézséget jelenthet a csoportos gyakorlat szervezési feltételeinek (a hallgatók kevés ideig, és kis csoportban vannak jelen az iskolában), illetve a szülőkkel való intim kapcsolat kialakításának (például fogadó órán) összeegyeztetése. Talán erre alkalmasabb lehetőség kínálkozik a hallgatók összefüggő egyéni gyakorlata során, 
amikor is sokkal hosszabb ideig, és személyre szabottabban történik a hallgatók kompeteciafejlesztése. Addig is fontos tapasztalat lehet a hallgatók számára néhány, a vezetőtanár által felvázolt esettanulmány, amikor egy-egy tanulóval kapcsolatos nehézség, probléma mentén képet kaphatnak a családi háttérről, a családdal kapcsolatos teendők lehetőségről, egyáltalán egy ilyen folyamat menetéről.

A hallgatói visszajelzések alapján a tárgyi feltételekkel való elégedettség szoros összefüggést mutatott a szaktárgy oktatásához kapcsolódó készségek, a különböző módszerek alkalmazásának és a taneszközök alkalmazásának fejlődésével. Éppen ezért fontos feladat a tárgyi feltételekben mutatkozó hiányosságok azonosítása és az infrastrukturális fejlesztés ilyen irányú előmozdítása.

A hallgatók, a vezetőtanárok és az egyetemi oktatók megítélése szerint az iskolai gyakorlatok hatékonyságát egyértelműen növelhetné, ha a jelölteknek több (különböző korosztályban és tanulócsoportban történő) óralátogatási/óratartási lehetőséget biztosíthatna az intézmény. A vezetőtanárok szerint a hatékonyság növeléséhez hozzájárulna továbbá, ha az egyetem és a gyakorlóiskola képzési tartalma és ütemezése összhangban lenne egymással, így nem fordulhatna olyan elö, hogy a jelöltek az egyetemi kurzusokon megszerzett elméletet nem tudják hasznosítani a gyakorlatban, vagy hogy előbb tartanak a hallgatók szaktárgyi órát, mintsem a szakmódszertani kurzust elvégezték volna. Megfontolásra javasolt tehát az egyetemi oktatók és a gyakorlóiskolai tanárok szorosabb együttműködése, valamint az egyetemi képzési tartalom és a gyakorlóiskolai tevékenységek összefésülése.

A Szakmai Fejlesztő Iskola modellje a képzésben részt vevő intézmények és érintett személyek egyenrangú viszonyán alapul, melyre a kutatás alapján a tanárképzés több szintjén is igény és szükség mutatkozik. Az egyenrangúság mellett az együttmüködés intenzitására vonatkozóan is fogalmazódtak meg igények. Folyamatos szakmai együttműködésre lenne szükség egyrészt azért, hogy a hallgatók a megfelelő időben, a megfelelő felkészültséggel legyenek jelen az intézményekben, másrészt azért, mert a képzési folyamathoz kapcsolódó elméleti és gyakorlati tevékenységek számának és tartalmának optimalizálása is fejlesztendő területként bontakozott ki. A jól múködő szakmai tanulóközösségekben az érintetteknek lehetőségük van tanulni egymástól. Különösen fontos lenne, hogy ennek a tanulóközösségnek a szülők is aktív tagjává válhassanak, mert ezzel a hallgatók felkészülését jelentősen segíthetnék. Ugyanígy megemlíthető az iskolatitkár, iskolapszichológus és a fejlesztőpedagógus szerepe is. Több lehetőséget kel- 
lene biztosítani a hallgatók számára az egyéni bánásmódot igénylő tanulókkal való tanórai (differenciálás) és a tanórán kívüli (felzárkóztatás, tehetséggondozás, pszichológiai) foglalkozások megfigyelésére (esetleg megtartására), illetve a szakemberekkel való együttmüködésre. Az együttmüködés továbbá ki kellene, hogy terjedjen a gyermekek és a tanárjelölt hallgatók tanulási szükségleteikre vonatkozó közös kutatásokra is.

\section{Irodalom}

15/2006. (IV.3.) OM rendelet az alap-és mesterképzési szakok képzési és kimeneti követelményeiröl.

http://www.felvi.hu/pub_bin/dload/jogszabalyok/15_2006_alap_mester_kkk_2 0080 201.pdf Letöltés ideje: 2018. 07. 12.

Antal László (1976): A tartalomelemzés alapjai. Magvető Kiadó, Budapest.

Bordács Margit - Lázár Péter (2002): Kedveskönyv. Gyerekekért SOS 90 Alapítvány - Dinasztia Tankönyvkiadó, Budapest.

Creating Effective Teaching and Learning Environments: First Results from TALIS (2009): OECD

Cooper, J. M. (ed., 2011): Classroom Teaching Skills. Cengage Learning, Wadsworth.

Darling-Hammond, L. (1994): Professional Development Schools: Schools to develop profession. Teacher College Press, New York.

Dudás Anna (szerk., 2011): Útmutató a tanári mesterképzés szakos hallgatók nevelési-oktatási gakorlatához. https://drive.google.com/file/d/0BzreRR_Yf1pNF9rS1djQmgtaFE/view Letöltés ideje: 2018. 07. 12.

Eszterházy Károly Főiskola Gyakorló Általános, Közép-, Alapfokú Művészeti Iskola és Pedagógia Intézet (2016): Nevelési program.

https://drive.google.com/file/d/0BzreRR-_Yf1pX1ZRT3kwcUFuTDg/view Letöltés ideje: 2018. 07. 12.

Eszterházy Károly Főiskola Gyakorló Általános, Közép-, Alapfokú Művészeti Iskola és Pedagógia Intézet (2016): Szervezeti és Müködési Szabályzat. https://drive.google.com/file/d/0BzreRR__Yf1pT0RrcHY5UjhFNXM/view Letöltés ideje: 2018. 07. 12.

Eszterházy Károly Főiskola Gyakorló Általános, Közép-, Alapfokú Művészeti Iskola és Pedagógia Intézet: Munkaterv (2016/2017). https://drive.google.com/file/ d/0BzreRR-_Yf1pc2MwcldlQ3B0WEU/view Letöltés ideje: 2018. 07. 12. 
Eszterházy Károly Főiskola Gyakorló Általános, Közép-, Alapfokú Művészeti Iskola és Pedagógia Intézet (2016): Házirend. https://drive.google.com/file/d/0BzreRR-_Yf1pNWQxOUpFelM5RGc/view Letöltés ideje: 2018. 07. 12.

Fehérvári Anikó (szerk., 2016): Pedagóguskutatások. Merre tart a pedagógusszakma? OFI, Budapest.

Feiman-Nemser, S. (2001): From Preparation to Practice: Designing a Continuum to Strengthen and Sustain Teaching. The Teachers College Record, 103. évf., 6. sz. 1013-1055. https://doi.org/10.1111/0161-4681.00141 Letöltés ideje: 2018. 07. 12.

F. Lassú Zsuzsa - Podráczky Judit - Glauber Anna - Perlusz Andrea - Marton Eszter (2012): Nemzetközi kutatások a szülői részvétel hatásáról. In: Podráczky Judit (szerk.): Szövetségben. Tanulmányok a család és az intézményes nevelés kapcsolatáról. ELTE Eötvös Kiadó, Budapest. 43-70.

Golnhofer Erzsébet (2001): Az esettanulmány. Műszaki Kiadó, Budapest.

Jancsák Csaba (2011): A tanárképzésben részt vevő hallgatók formálódó világa. In: Ercsei Kálmán - Jancsák Csaba (szerk.): Tanárképzős hallgatók a bolognai folyamatban (2010-2011). OFI, Budapest. 27-53.

Jancsák Csaba (2012): A tanárképzés hallgatói megítélése. In: Balog Iván et al (szerk.): A szociológia szemüvegén keresztül - Tanulmányok Feleky Gábor 60. születésnapjára. Belverde Meridionale, Szeged. 107-121.

Kállai Gabriella - Szemerszki Marianna (2016): Pedagógushallgatók. In: Fehérvári Anikó (szerk.): Pedagóguskutatások: Merre tart a pedagógusszakma? OFI, Budapest. 9-52.

Kopp Erika - Kálmán Orsolya (2015): Nemzetközi tapasztalatok elemzése a tanítási és az összefüggő egyéni gyakorlat terén. In: Rapos Nóra - Kopp Erika (szerk.): A tanárképzés megújítása. ELTE Eötvös Kiadó, Budapest. 97-148.

Krist, D. - White, J. - Whitelaw, L. (2016): PDS Partnership Ideas to Promote College and Career Readiness. NAPDS Conference, Washington D.C, 2016 March 3-6., PDS Partners, 11. évf. 3. sz., 15.

Kocsis Mihály (2003): A tanárképzés megitélése. Iskolakultúra-könyvek 18. Iskolakultúra, Pécs.

Ligeti György - Márton Izabella (2002): Jelentés a "Szülők és az iskola" címú kutatás eredményeiről. Kurt Lewin Alapítvány, Budapest.

Lukács Péter et. al. (2002): A pedagógusképzés megújitásához I. Oktatáskutató Intézet, Budapest.

Murray, J. - Swennen, J. - Kosnik, C. (2019): International Research, Policy and Practice in Teacher Education. Springer International Publishing. https://doi.org/10.1007/978-3-030-01 612-8 Letöltés ideje: 2018.07.12. 
N. Kollár Katalin (2008): Pedagógusok pályaképe, a tanárképzéssel való elégedettségük nehézségeik. Pedagógusképzés, 6. évf. 35. sz. 5-29.

N. Kollár Katalin (2011): Tanárjelöltek pályaképe, képzéssel való elégedettségük és nehézségeik. Pedagógusképzés, 9. évf. 38. sz. 5-29.

Polyák Teréz - Sófalvy Anna (2008): Családbarát iskola. Adalékok az integrációs nevelés pedagógiájához. Educatio Társadalmi Szolgáltató Közhasznú Társaság, Budapest.

Sági Matild - Szemerszki Marianna (2016): A pályakezdő pedagógusok szakmai fejlődési igényei és azok megvalósulása. In: Fehérvári Anikó (szerk.): Pedagóguskutatások: Merre tart a pedagógusszakma? OFI, Budapest. 53-94.

Sándor József (szerk., 2011): Utmutató a tanári mesterképzés szakos hallgatók iskolai, szakmai, tanitási gyakorlatához. https://drive.google.com/file/d/0BzreRR_Yf1pV3FGc1d0UmJqeXM/view Letöltés ideje: 2018. 07. 12.

Sántha Kálmán (2015): Trianguláció a pedagógiai kutatásban. ELTE Eötvös Kiadó, Budapest.

Szemerszki Mariann (2015): Pedagógusok szakmai kompetenciáinak és továbbképzési igényeinek életkor szerinti eltérései. In. Sági Matild (szerk.): A pedagógushivatás megerösitésének néhány aspektusa. OFI, Budapest. 34-56.

Zeichner, K. (2010): Rethinking the connections between campus courses and field experiences in college- and university-based teacher education. Fournal of Teacher Education, 61. évf. 1-2. sz. 89-99.

https://doi.org/10.1177/0 022487109347671 Letöltés ideje: 2018.07.12.

\section{The Role of the University-Based Practice Schools in Pre-Service Teachers' Professional Preparation}

National and international literature data have demonstrated that teacher trainees are dissatisfied with many areas of initial teacher education (Kocsis, 2003; Lukács, 2002; Jancsák, 2011, 2012). These reports have been largely confirmed by research into novice teachers' professional problems (Hagger and McIntyre, 2006; OECD, 2009; Fehérvári 2016). The aim of this case-study, conducted in the Practice School of Eszterházy Károly University in 2017, was to examine these issues in the current Hungarian context, and propose possible solutions with regard to the Professional Development School model.

Key words: (initial) teacher education, pre-service teachers, university-school partnership 